\title{
Loss and Damage Assessment in the Context of Fire Hazards: A Study on Selected Garment Factories in Bangladesh
}

\author{
Md. Mizanuzzaman \\ Institute of Disaster Management and Vulnerability Studies, University of Dhaka, Dhaka, Bangladesh \\ Email address: \\ mizanuzzaman@gmail.com
}

\section{To cite this article:}

Md. Mizanuzzaman. Loss and Damage Assessment in the Context of Fire Hazards: A Study on Selected Garment Factories in Bangladesh. International Journal of Finance and Banking Research. Vol. 2, No. 2, 2016, pp. 24-39. doi 10.11648/j.ijfbr.20160202.11

Received: January 9, 2016; Accepted: January 14, 2016; Published: April 28, 2016

\begin{abstract}
This research paper has discussed comprehensively about the concept, classification, estimating methods and grading standards of economic losses of fire in garments industries in Bangladesh. The contents of economic losses of industrial fire include the losses of industrial resources" direct economic losses, indirect economic losses and the economic losses on ecological environment. Different estimating methods are adopted for each of them: And, according to the amount of economic losses, industrial fires are divided into extraordinarily serious industrial fire, serious industrial fire and ordinary industrial fire. Most of the fire hazards in RMG sector occurs causing electric short circuit in Bangladesh. And this occurrence creates huge economic damage and loss in this sector. In order to attach of the store house or go down with the factory it becomes impossible to out let of the goods from the store house which happens great loss. Distance of fire station is another reason to control of fire. Locked and narrow emergency exits, panic, dark stairway, full of smoke and the electricity supply been shut down and suffocation for the smoke are the main reasons for death and casualty in the garments factories in our country. Owner of the factory should give remarkably importance in electric supply line, wearing cables and electrical equipments. Government should take steps to operate mobile courts in factory level regularly to ensure occupational safety \& health.
\end{abstract}

Keywords: Loss and Damage Assessment, Fire Hazards, Garment Factories, Bangladesh

\section{Introduction}

Bangladesh is one of the most disaster-prone countries in the world. The country has had several experiences of natural and human induced disasters. It is a low-lying deltaic country in South Asia and divided into three zones, namely hills, terraces and flood plain. The country has an approximate area of 147,570 sq.km bounded between $20^{\circ} 34^{\prime}$ to $26^{\circ} 38^{\prime} \mathrm{N}$ latitude and $88^{\circ} 01^{\prime}$ to $92^{\circ} 41^{\prime} \mathrm{E}$ longitude. Bangladesh being in close proximity with the Himalayas by the north and the Bay of Bengal by the south. Due to the geographical location, the country mainly the coastal area is more vulnerable which represents an area of 47,211 km2, 32 percent of the country's geographical area frequently suffers from devastating natural hazards. Since independence in 1971, Bangladesh has achieved substantial improvements in some social indicators like a decrease in infant and maternal mortality as well as illiteracy, and an increase in life expectancy, access to safe water and sanitation. The economic performance of the country has been relatively strong since 1990 , with an annual $6.5 \%$ average GDP growth rate. In this context the of RMG sector is keeping contribution to improve our national economy remarkably.

Rebuilding the war-ravaged country of Bangladesh with limited resources appeared to be the biggest challenge for us after the independence in 1971. To progress the country's economy, industrialization may keep crucial contribution. Once upon a time our jute industries kept a vital role to enrich our national economy. When our lone export earner the jute industry started losing its golden days, it is the RMG sector that replaced it, and then, to overtake it. The readymade garment (RMG) industry which is now the single biggest export earner for Bangladesh. Bangladesh received more than three fourth (about 81.32\%) of total export earnings from Readymade garments (Woven and Knitwear). Total export of Readymade Garments rose by 7.9 percent year-on-year in January-March 2015 and their growth significantly increased by 14.0 percentage points from the previous quarter, October-December 2014. (Bangladesh 
Bank Quarterly Review on RMG: January-March 2015).

In Bangladesh there are 4222 garments factories and about 4 million employees engaged in RMG sector, 85 percent of which is women. According to BGMEA, 30 percent capacity of RMG sector is unutilized due to lack of skilled labor force. Since 2005 employment in RMG sector increases from 2 million to 4 million in FY 2014. As well as number of active factories increases from 4107 to 5600 in 2012-13. However, in 2013-14 the number of factories stood at 4222 (BGMEA. * Included in BGMEA Member List).

The apparel industry of Bangladesh started its journey in the 1980s and has come to the position it is in today. The late Nurool Quader Khan was the pioneer of the readymade garment industry in Bangladesh. He had a vision of how to transform the country. In 1978, he sent 130 trainees to South Korea where they learned how to produce readymade garments.

With those trainees, he set up the first factory - Desh Garments - to produce garments for export. At the same time, the late Akhter Mohammad Musa of Bond Garments, the late Mohammad Reazuddin of Reaz Garments, Md. Humayun of Paris Garments, Engineer Mohammad Fazlul Azim of Azim Group, Major (Retd) Abdul Mannan of Sunman Group, M Shamsur Rahman of Style craft Limited, the first President of BGMEA, AM Subid Ali of Aristocrat Limited also came forward and established some of the first garment factories in Bangladesh.

Despite the epic growth of our RMG industry, and its bright prospects, challenges are still there. One of the biggest challenges currently faced by our RMG industry is to ensure workplace safety and better working conditions for the millions of garment workers.

Two major accidents, the Tazreen fire and the Rana Plaza collapse, have brought the issue of workplace safety to the fore and led all stakeholders to act accordingly. Following the unfortunate incidents, various platforms such as the Bangladesh Accord on Fire and Building Safety, the Alliance for Bangladesh Worker Safety and National Plan of Action have been formed to improve building and fire safety of Bangladesh's garment industry.

Natural and man-made hazards may affect industrial production sites by both direct losses (due to physical damage to assets and buildings) and indirect losses (production losses). Indirect losses, e.g. from production downtimes, can exceed direct losses multiple times. Thus, the vulnerability and risks of industrial sectors and to determination of its losses is an important component for analyzing damage and loss assessment. In this paper a theoretical conceptual indicator framework are presented which allow assessing the direct and indirect damage and loss of industrial sectors to fire disasters in a quantitative manner. The results are useful for information sharing and decision making in crisis management and emergency planning (mitigation measures, business continuity planning), since the developed indicator system helps to take the complex phenomenon of industrial vulnerability and the underlying interdependencies into account. Besides the identification and conceptual motivation of the indicators, methodical aspects such as standardization, weighting and aggregation are addressed.
Every year small and large scale of fire in garments factory resulting huge economic damage and loss is a common phenomenon in our country. Damage and Loss depends on different indicators (e.g. magnitude of the fire, flame ability, degree of destroyed materials, loss of life, injury, ecological impact etc.). According to information of Bangladesh Fire Service and Civil Defence 2427 small and large scale of fire occurrences have been occurred in RMG sector in Bangladesh from the year of 2000-2014 in which loss has determined BDT 8997426164, death 368 and injured 680. To prepare this thesis six remarkable fire incidents and their impacts have been observed. The observing factories are Tazreen Fashion, Smart Fashion Export Factory, Tung Hai Sweaters Ltd, Aswad Composite Mills Limited, Standard Group and Mega Yarn Dyeing Mills Limited. From the visited factories loss for the causing fire BDT 31110710177 , death 140, injured 392 and jobless 23100 have been estimated. From the secondary data source 72 fire incidents of garments and textile industries have been observed which occurred within the year of $1990-2015$. In this case $70 \%$ of accidents occurred by electric short circuit. If we estimate the total losses suffered by selected observed factories and loss of fire incidents from $2000-2014$ amounted that approximately BDT 40108136341, which would be approximately 0.50 per cent of GDP for FY2015.

\section{Literature Review}

Within this paper I would like to present the estimation of economic loss due to fire in the garments industries of Bangladesh. In this regards different works of the following have been read to understand on it which could be helpful for me. On the basis of their works I have tried to enhance my ideas. Andersson (1997) tried to concentrate on the hazard evaluation in industry and why industrial fire safety has become of increasing importance and also how industrial fire risk analysis should be conducted, in order to meet the demands of both society and industry. Jonkman, Gelder and Vrijling (2002) carried out risk literature aimed at giving an overview of quantitative risk measures in The Netherlands for flooding. In this article he focused mainly on risk measures that consider loss of life and economic damage as a consequence. Hiete and Merz (2009) tried to develop a conceptual framework for the determination of indirect vulnerability of industrial sectors. This framework aims at assessing the overall disaster vulnerability (social, industrial, environmental) of different regions in Germany. The volume - 2 of World Bank Journal (2010) identified damage, loss and need assessment process how to reduce the social, economic and financial implications of disasters and using this methodology to reinforce resilience by promoting the "Build Back Better" principles. Stokes, Dixon, Molano \& Nana (2012) reported fire damage in non-residential buildings, cost of replacing and repairing buildings, the loss of building contents in New Zealand. They also include estimates of damage from unreported fires, and indirect damage caused by fires in non-residential buildings and human factors loss of life and injury. ABIR (2014) tried to explore the fire hazard vulnerability hazard management scenario of garments industries in Dhaka from the point of institutional 
capacity of Bangladesh Fire Service and Civil Defense (BFSCD). Wadud, Huda and Ahmed in their work (Assessment of Fire Risk in the Readymade Garment Industry in Dhaka, Bangladesh) tried to explore on understanding the status of the 'soft' parameters in fire safety management rather than on the 'hard' parameters which is often the focus of the fire safety certification process. National Human Rights Commission, Bangladesh (2014) urged to justify and investigate the main loopholes of the present labour law of Bangladesh with the support of national and international legal framework for the security and safety of the garments workers in Bangladesh.. Hall (2014) tried to identify the total cost of fire in USA as an economic value with the donated time of volunteer firefighters and cost of deaths and injuries. Biswas (2000), express in his book (Insurance and Risk Management) how to calculate loss for fire insurance. Faruqe (2015), explains in his book (Compliance \& Audit) about the development of compliance sector duties and responsibilities of the garments sector which helps the study better. CPD's Rapid Assessment of Flood 2004, (2005), Options for Self-reliant Resurgence helps to use numerical formula to calculate loss for this study.

\section{Background of the Research}

Bangladesh is a financially grown up country. In this context RMG sector keeps a vital role to improve our economy. But sometimes some unavoidable incidents like fire, building collapse, political unrest, sabotage etc. are greatly influencing the RMG sector in our country. Every year several incidents of fire are creating huge loss and damage in several garments factories and Bangladesh losses millions of foreign currency. Considering this factor, this study has tried to show and analyze the damage and loss due to fire in six selected garments factory named Tazreen Fashion, Smart Fashion, Tung Hai Sweater Limited, Aswad Composite Mills Limited, Standard Garments and Mega Yarn Dyeing Mills Limited and 72 fire occurrence since 19902015 by analyzing primary and secondary data. For this reason a questionnaire is prepared, 30 interviews with the questionnaire besides this KII for 25 persons and secondary data analysis on it have been conducted. By these deeds I have tried to analyze data due to fire in the garments sector and their loss in our country.

\section{Objectives of the Research}

- To estimate economic loss due to fire occurrences in the selected garment factories in Bangladesh.

- To know the facilities available for the prevention of fire accidents in the factories.

- To find out the causes of the accident.

- To suggest for better management of the fire accidents.

\section{Research Methodology}

Following two types of methods have been followed for acquiring and analyzing data.

Process of Data Acquisition: This study has employed both qualitative and empirical approach because of mixed nature of the problem with a view to achieving the best outcome of the research. The qualitative methodology of research has been applied for subjective assessment based on secondary sources to investigate the loopholes in the fire accidents of RMG sector and the safety and security net of the garments workers in Bangladesh. While doing this part of the research, the existing literatures on the fire of garments industries, insurance for fire, estimation of fire risk, estimation of fire loss and labor laws have been explored and examined thoroughly. Some questionnaires are designed in such manner so that the executive body of the RMG sector and garments workers can express their opinions without any prejudice and bias finding the obstacles as to safety net in consonance with ILO Conventions and standards. The findings of the mixed approach will be categorized systematically and the common findings will be offered as recommendation to amend the current labor and industrial law in the country: Secondary, Data source,KII

Process of Data Analysis: Collecting data has been analyzed by applying following methods to achieve results.

Concept of Economic Losses in Industrial Fire: Economic losses of industrial fire refer to the economic losses which reach certain amounts caused by fire. Typical losses include the decline in output in productive sectors (agriculture, livestock, fisheries, industry and commerce) and the lower revenues and higher operational costs in the provision of basic services (water and sanitation, electricity, transport), as well as the unexpected expenditures to meet humanitarian needs during the post-disaster emergency phase.

Methods of the Economic Loss Estimation of Industrial Fire

The estimation of economic loss of industrial fire has adopted a method of estimating by classes. That is, based on the estimation of economic loss of each class, get the total amount of loss caused by each industrial fire.

Loss of standing resources: refers to the value of real burnt stock volume within the industrial land area caused by each industrial fire, estimated by different things.

The estimating formula is ${ }^{n}$

Where,

$$
\mathrm{L}=\sum_{\mathrm{i}=1}^{n} \mathrm{ViRi}
$$

$\mathrm{L}=$ the amount of economic loss of standing resources;

$\mathrm{V}=$ the loss of stock volume;

$\mathrm{R}=$ price of standing resources;

$\mathrm{i}=$ different things, $\mathrm{i}=\mathrm{I}, 2,3 \ldots \mathrm{n}$.

The formula for estimating the loss of stock volume $(V)$ is, loss of stock volume $(\mathrm{V})=$ average stock volume per unit area $\left(\mathrm{V}^{\prime}\right) \mathrm{X}$ fully destroyed rate $(\mathrm{P}) \mathrm{X}$ burnt area $(\mathrm{S})$

Every single thing is investigated, classified as burnt thing, damaged thing or non burnt thing, and the losses are defined accordingly.

The determination ' of the price of standing resources $(R)$

Due to the current price policy of Bangladesh and the different ' situation in the factory area, there are market price inverse estimating method, theoretical cost price estimating method and current planning' price estimating method to determine the price of standing resources $(\mathrm{R})$.

Market price inverse estimating method:

The formula for the price of standing resources $(\mathrm{R})$ is 
$\mathrm{R}=$ market price of finished goods - logging expenses circulation costs among which, logging expenses: (I) logging expenses; (II) management expenses;

(III) others circulation costs: (I) transport costs; (II) loading and unloading expenses;(III) management expenses; (IV) others

\section{Theoretical cost price estimating method}

According to the basic theory or" factory resources reproduction and in order to ensure the reasonable profit of the resource producers, based on the real expenses and costs, we formulated the list of theoretical cost price of resources in a factory, in which the price level of standing resources of everything at different goods scan be directly found. Investigation can also be carried out in combination with the actual local situations.

Direct Economic Loss

Finished goods, processing goods and Raw materials byproducts: All the finished goods, processing goods such as: process flow chart (issue to floor $\rightarrow$ goods in cutting section $\rightarrow$ goods in sewing section $\rightarrow$ goods in washing section $\rightarrow$ goods in ironing section $\rightarrow$ goods in packaging section) and raw materials by-products, etc. that are burnt or affected by the reaching of industrial fire at the places including logging site, raw materials storage, finished goods storage and stocking yard.

- The formula for the estimation of the finished things loss in the logging site is: loss (Tk.) = quantity of lost things $\mathrm{X}$ production cost price of that things (category wise) (Tk.) - left value of things (Tk.)

- The formula for the estimation of the processing goods loss on stocking yards is: loss (Tk.) = quantity of lost things (sector wise) X producer price (Tk.) - left materials value (Tk.)

- The formula for the estimation of the loss of raw materials is: loss (Tk.) = quantity of lost raw materials (pcs./others) $\mathrm{X}$ price of the thing (as per unit Tk.) value of left things (Tk.)

The formula for the estimation of the loss of things byproducts is: loss (Tk.) = quantity of things by-products (per pcs/unit) X market price of the product (per pcs/unit)

Fixed assets: The loss of fixed assets (including industrial or civil buildings, machines and equipments, instruments and meters, vehicles, boats and ships, etc.) burnt by industrial fire is estimated by re-purchase complete value depreciation method.

The formula is: loss (Tk.) = re-purchase complete value (Tk.) X (1 - average rate 'of depreciation per year/month \% X number of years/month of service) $\mathrm{X}$ burn rate (\%)

Repurchase complete value refers to the money needed to rebuild or repurchase the fixed assets. The figures can be found. from the local regulations of the house property administrative department and relative departments. If it cannot be determined under special circumstances, the original value can be used for estimation instead of repurchase complete value. Among the. formula, burn rate refers to the real degree of burnt in terms of percentage.

Mobile Assets: It refers to the property that takes part in the circulation during the production and management process and changes its forms, such 'a $\mathrm{s}$ raw material, materials, ' fuel, being manufactured articles, semi-finished products, and products, etc.

The formula is :loss (Tk.) = quantity of mobile assets $\mathrm{X}$ buying -price -left value It is estimated separately according to different kinds of mobile assets, and added up together.

Loss of products of agriculture and animal husbandry in factory areas:

The loss of products of agriculture (such as grains, cotton and oil, etc.) and animal husbandry (such as animal and domestic fowl, etc.) in factory areas is estimated separately by each kind.

Economic loss on agricultural production refers to the damage of different crops surrounded by that industry which is affected by the fire and it is estimated by the following formula:

$$
\mathrm{TD}_{\mathrm{c}}=\sum_{j}(\mathrm{Qi} * \mathrm{Pi})+\sum \mathrm{Di}
$$

Where,

$\mathrm{Q}_{\mathrm{i}}$ Quantity of crop damage for i-th crop in metric ton

$\mathrm{P}_{\mathrm{i}}$ Wholesale price of the $\mathrm{i}$-th damaged crop per metric ton in TK.

Di Lump sum damage estimate for i-th crop in Tk.

Cost of fire protection: This item is the annual average cost of purchasing various fire protection facilities and building fire roads and all the expenses of fire protection team, in order to prevent industrial fire, within a certain period from which the cost of per unit area can be estimated according to destroyed or damaged area. The cost of per unit area multiplied by burnt area is the loss of fire protection expenses.

The formula is: fire protection cost $(\mathrm{Tk})=$. fire protection cost. per unit industrial (sq feet/sq. meter) $\mathrm{X}$ burnt area

Indirect Economic Loss

Stop production, drop in production and close down of business refer to stop production, drop in production because of reducing. managing activities and loss. in the volume of business influenced by industrial fire of the factories of raw materials production, raw materials processing, machinery and other industrial sectors and of the sale and commercial units of industrial products. The estimation method is:. loss from stop production $(\mathrm{Tk}$.) = output of products per unit time $\mathrm{X}$ stop production time $\mathrm{X}$ ex-factory price per unit product loss from close down of business (Tk.) = turnover per day $\mathrm{X}$ number of days of closure

Personnel death and wound: According to the degree of wound it is divided into three classes.

(I) light wound -- the wound that causes loss of ability and the loss is less than 105 working days;

(II) Serious wound -- the wound that causes loss of ability and the loss is 105 or more working days but less than 6,000 days;

(III) Death - - estimated as loss of 6,000 working days loss of personnel death and wound (Tk.) = number of the dead and wounded (person) X number of working days lost ability (day) X salary of different staff (Tk.)

On-the-spot rescue and treatment: includes materials used in fire suppression and the salary of fire fighting personnel.

Expenses of dealing with the aftermath: 
- Costs of swamping fire slash and fire site, it is estimated according to the real costs.

- Pension and medical expenses for the dead and wounded people, it is estimated according to the real costs.

Business Interruption Loss:

The term business interruption usually describes the disruption of typical operations as a result of a definable event that is beyond the entity's control. In legal contracts and insurance policies, business interruption means the financial impact of such a disruption over a period of time.

The business interruption formula can be summarized as follows.

$\mathrm{BI}=\mathrm{T} * \mathrm{Q} * \mathrm{~V}$

Where:

$\mathrm{BI}=$ business interruption and:

$\mathrm{T}=$ the number of time units (hours, days) operations are shut down

$\mathrm{Q}=$ the quantity of goods normally produced, or sold, per unit of time used in $\mathrm{T}$

$\mathrm{V}=$ the value of each unit of production, usually expressed in profit

Biological Economic Loss / loss on ecosystem:

Industrial fire has destroyed the biological balance in the forest area, caused deterioration of biological environment and reduced the productivity of forest land. Moreover, the villages and farmlands nearby have lost shelter which endangers the agricultural production and the people's life, and leads, to the deterioration of the production and life environment. Therefore, it is difficult to estimate accurately the loss on the biological environment caused by industrial fire. Considering the current situations and possibilities, estimate only three kinds of loss, i.e. economic loss on agricultural production, economic. loss on ecosystem and loss of wildlife. For the time being, it will be added and perfected by further research and practice.

Loss of wildlife refers to the economic value of lost wildlife in that area after industrial fire. Loss of wildlife (Tk.)
$=$ (quantity of wildlife of that area $\mathrm{X}$ average current price of wildlife

Grading of Industrial Fire Loss:

On regards to the relevant standards of Bangladesh, fires on RMG sectors are graded into three classes on the basis of the amount lost in resources, property and personnel death and wound caused by one industrial fire:

Class I: Extraordinarily serious industrial fire, the loss of it is more than BDT 100 crore;

Class II: Serious industrial fire, the loss of it is between BDT 50 crore - 100 crore;

Class III: Ordinary industrial fire, the loss of it is less than BDT 50 crore

\section{Limitation of the Research}

Every research has not beyond of limitation. My research has several limitations. This study is primarily limited by its small sample size. Although the use of expert judgments is a fairly common approach to studying alignment, this study does not provide complete picture assessments. I have not, for example, systematically examined differences in content standards or test specifications, which may account for some of the discrepancies among exams. Furthermore, an analysis of large sample data may have given a good result for this study. On the other hand lack of information and support logistically this paper cannot furnish the result of environmental impacts due to industrial fire especially fire of those factories. Finally, the expenses or losses dealing with aftermath for those incidents (for example: impacts of injured survived workers, disabled personnel and their families and the owners of the factories) did not possible to identify.

\section{Analysis of Data: Results and Discussion (Field Survey - 2015)}

Fire Occurrence \& Impacts Scenario of the Observed Garments at a Glance

Table 1. Fire Occurrence \& Impacts Scenario of the Observed Garments at a Glance.

\begin{tabular}{|c|c|c|c|c|c|c|c|c|}
\hline $\begin{array}{l}\text { Name of } \\
\text { Company }\end{array}$ & $\begin{array}{l}\text { Date of } \\
\text { Occurrence }\end{array}$ & $\begin{array}{l}\text { Time of } \\
\text { Occurrence }\end{array}$ & Causes of Occurrence & $\begin{array}{l}\text { Total } \\
\text { Workers }\end{array}$ & Death & Injured & Jobless & $\begin{array}{l}\text { Total Loss of the Company } \\
\text { (Approximate) BDT }\end{array}$ \\
\hline $\begin{array}{l}\text { Tazreen } \\
\text { Fashion }\end{array}$ & 24-Nov-2012 & 6: $00 \mathrm{pm}$ & $\begin{array}{l}\text { The fire, presumably caused } \\
\text { by a short circuit }\end{array}$ & 1400 & 111 & 300 & 700 & 5654166667 \\
\hline $\begin{array}{l}\text { Smart } \\
\text { Fashion } \\
\text { Export } \\
\text { Factory }\end{array}$ & 26-Jan-2013 & $2: 30 \mathrm{pm}$ & $\begin{array}{l}\text { There was a tire repair and } \\
\text { wielding workshop } \\
\text { downstairs so officials say } \\
\text { that the fire could have } \\
\text { started from this point. }\end{array}$ & 450 & 10 & 35 & 400 & 1295750000 \\
\hline $\begin{array}{l}\text { Tung Hai } \\
\text { Sweaters Ltd } \\
\text { Aswad }\end{array}$ & 08-May-2013 & 11: $00 \mathrm{pm}$ & $\begin{array}{l}\text { The fire, presumably caused } \\
\text { by a short circuit }\end{array}$ & 2700 & 08 & 03 & 0 & 1999250000 \\
\hline $\begin{array}{l}\text { Composite } \\
\text { Mills } \\
\text { Limited }\end{array}$ & 08-Oct-2013 & $5: 45 \mathrm{pm}$ & $\begin{array}{l}\text { The cause of the blaze was } \\
\text { not known }\end{array}$ & 2550 & 10 & 50 & 2000 & 2251493510 \\
\hline $\begin{array}{l}\text { Standard } \\
\text { Group }\end{array}$ & 29-Nov-2013 & 12: $00 \mathrm{am}$ & Sabotage & 25000 & 0 & 0 & 20000 & 19278750000 \\
\hline $\begin{array}{l}\text { Mega Yarn } \\
\text { Dyeing Mills } \\
\text { Limited }\end{array}$ & & & Total: & 32,600 & 140 & 392 & 23,100 & 31110710177 \\
\hline
\end{tabular}




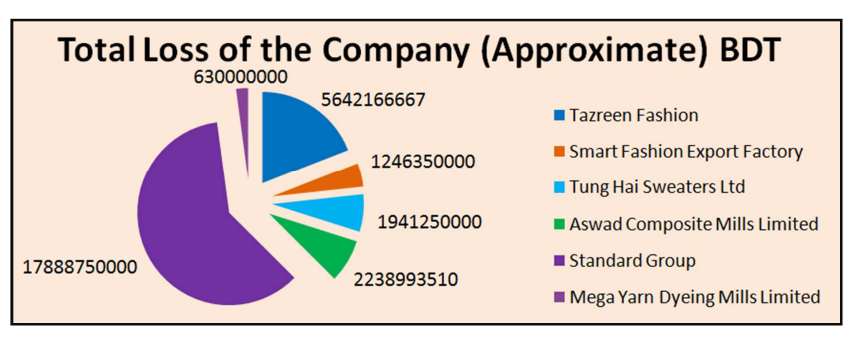

Figure 1. Loss Scenario of those Companies.

\section{Fire Incidents and Losses of the Selected Garments}

Total economic loss for the happening of several fire incidents of that industry is estimated BDT 31110710177 within the year of 2012- 2014. This estimation is based on the previously stated methodological definition and formula.
It defines the total losses causing fire occurrence directly or indirectly of that industries. Net losses of those industries have been calculated and try to focus in this table. On the other hand this table shows that total employees are 32600 , death 140, injured 392 and jobless 23100 of that six industries. Most of the occurrence has been occurred within evening to night except Smart Fashion. Electric short circuit is the main issue of happening fire. Slandered Group is one of the biggest group of companies in our country but due to political un restless instigated to set fire of the garments by workers of Standard Group along with some non-workers stormed and torched the company. So, the fire of Standard is considered as sabotage.

Table 2. Loss Scenario of Infrastructure.

\begin{tabular}{|c|c|c|c|c|c|c|c|c|}
\hline Name of Company & $\begin{array}{l}\text { Building } \\
\text { Structured } \\
\text { (Stored) }\end{array}$ & $\begin{array}{l}\text { Total Area } \\
\text { (Sq. Ft.) }\end{array}$ & $\begin{array}{l}\text { Affected } \\
\text { Area (Sq. } \\
\text { Ft.) }\end{array}$ & $\begin{array}{l}\text { Affected/Dama } \\
\text { ged Area \% }\end{array}$ & $\begin{array}{l}\text { Total Damage } \\
\text { (BDT) }\end{array}$ & $\begin{array}{l}\text { Total } \\
\text { Recovery } \\
\text { (BDT) } \\
\end{array}$ & $\begin{array}{l}\text { Recovery } \\
(\%)\end{array}$ & $\begin{array}{l}\text { Net Loss } \\
\text { (BDT) }\end{array}$ \\
\hline Tazreen Fashion & 9 & 51000 & 49000 & $96 \%$ & 500000000 & 50000000 & $10 \%$ & $45,00,00,000$ \\
\hline $\begin{array}{l}\text { Smart Fashion } \\
\text { Export Factory }\end{array}$ & 2 & 10000 & 10000 & $100 \%$ & 5000000 & 1000000 & $2 \%$ & $40,00,000$ \\
\hline $\begin{array}{l}\text { Tung Hai Sweaters } \\
\text { Ltd }\end{array}$ & 11 & 125000 & 35000 & $28 \%$ & 100000000 & 5000000 & $5 \%$ & $9,50,00,000$ \\
\hline Standard Group & $10+10$ & 1680000 & 1680000 & $100 \%$ & 3000000000 & 750000000 & $25 \%$ & $225,00,00,000$ \\
\hline $\begin{array}{l}\text { Mega Yarn Dyeing } \\
\text { Mills Limited }\end{array}$ & 7 & 153152 & 21000 & $14 \%$ & 10000000 & 50000000 & $50 \%$ & $50,00,000$ \\
\hline Total & & & & & & & & $375,40,00,000$ \\
\hline
\end{tabular}

Source: Field Survey 2015

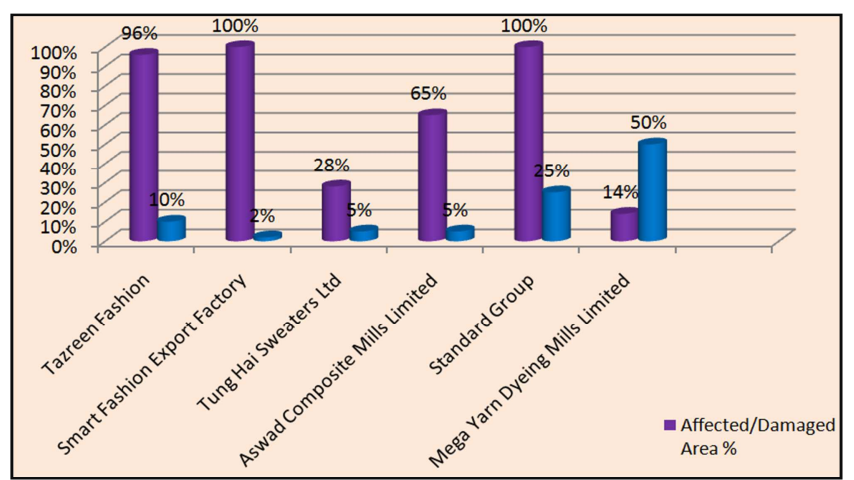

Figure 2. Loss of Affected Infrastructure.

Loss of Affected Infrastructure

Among the loss of different sectors, physical damage of infrastructure and the economic loss of it are very much essential. Table: 2 shows that total economic loss of infrastructure of the six observed factories is BDT 3754000000 (Approx.). Specifically if we try to explain, Tazreen Fashion is a 9 storey building conceives of 51000 sq. ft. About $96 \%$ which indicates 49000 sq. ft. was affected during setting fire. Loss of affected area which damaged major parts of the factory and only $10 \%$ of the affected was recovered, total damage was considered in amount BDT 500000000 (Approx.). By this table it clearly shows that severely affected factories are Smart Fashion and Standard Group. Both the factories were fully (100\%) affected and recoveries were very poor. Amongst them less affected factory is Mega Yarn Dyeing Mills Limited. It was affected only $14 \%$ and its recovery was $50 \%$.

Table 3. Loss of Machinery.

\begin{tabular}{|c|c|c|c|c|c|c|c|}
\hline Name of Company & $\begin{array}{l}\text { Total } \\
\text { Machinery }\end{array}$ & $\begin{array}{l}\text { Affected } \\
\text { Machinery }\end{array}$ & $\begin{array}{l}\text { Affected } \\
\text { Machinery (\%) }\end{array}$ & $\begin{array}{l}\text { Total Machinery } \\
\text { Damage (BDT) }\end{array}$ & $\begin{array}{l}\text { Total Recovery } \\
\text { (BDT) }\end{array}$ & Recovery (\%) & $\begin{array}{l}\text { Net Loss } \\
\text { (BDT) }\end{array}$ \\
\hline Tazreen Fashion & 650 & 650 & $100 \%$ & $200,00,00,000$ & $20,00,00,000$ & $10 \%$ & $180,00,00,000$ \\
\hline $\begin{array}{l}\text { Smart Fashion Export } \\
\text { Factory }\end{array}$ & 250 & 250 & $100 \%$ & $1,00,00,000$ & $5,00,000$ & $5 \%$ & $95,00,000$ \\
\hline $\begin{array}{l}\text { Tung } \\
\text { Hai Sweaters Ltd }\end{array}$ & 650 & 110 & $16 \%$ & $200,00,00,000$ & $5,00,00,000$ & $10 \%$ & $195,00,00,000$ \\
\hline $\begin{array}{l}\text { Aswad Composite } \\
\text { Mills Limited }\end{array}$ & 800 & 480 & $60 \%$ & $100,00,00,000$ & $1,00,00,000$ & $1 \%$ & $99,50,00,000$ \\
\hline Standard Group & 1500 & 1500 & $100 \%$ & $700,00,00,000$ & $70,00,00,000$ & $10 \%$ & $630,00,00,000$ \\
\hline
\end{tabular}




\begin{tabular}{llllllll}
\hline Name of Company & $\begin{array}{l}\text { Total } \\
\text { Machinery }\end{array}$ & $\begin{array}{l}\text { Affected } \\
\text { Machinery }\end{array}$ & $\begin{array}{l}\text { Affected } \\
\text { Machinery (\%) }\end{array}$ & $\begin{array}{l}\text { Total Machinery } \\
\text { Damage (BDT) }\end{array}$ & $\begin{array}{l}\text { Total Recovery } \\
\text { (BDT) }\end{array}$ & Recovery (\%) & $\begin{array}{l}\text { Net Loss } \\
\text { (BDT) }\end{array}$ \\
\hline $\begin{array}{l}\text { Mega Yarn Dyeing } \\
\begin{array}{l}\text { Mills Limited } \\
\text { Total }\end{array}\end{array}$ & 400 & 60 & $15 \%$ & $25,00,00,000$ & $8,75,00,000$ & $35 \%$ & $16,25,00,000$ \\
\hline
\end{tabular}

Source: Field Survey 2015

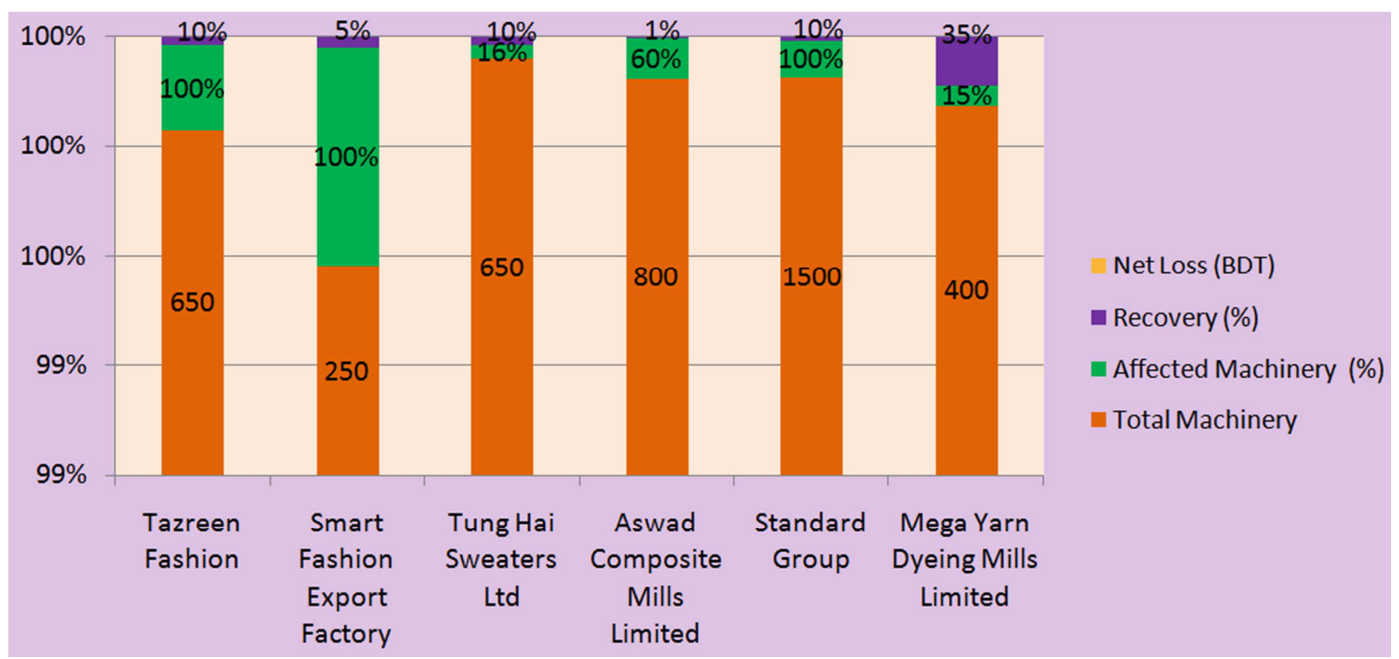

Figure 3. Loss of Affected Machinery.

\section{Loss of Machinery}

A factory is equipped by different types of machinery or equipments. Here considerate machinery is sewing machine, knitting machine, linking machine and jacquard machine etc. for the calculation of loss of production equipments. The equipments of those factories were fully $(100 \%)$ affected indicates the table are Tazreen Fashion, Smart Fashion and Standard Group and their rate of recovery respectively $10 \%$, $5 \% \& 10 \%$. The machinery of Tung Hai Sweaters Limited and Mega Yarn Dyeing Mills Limited were affected 16\% \& $15 \%$ respectively and rate of recovery were $10 \% \& 35 \%$. Amongst of the six factories the lowest recovery is seen from the table 1\% indicates Aswad Composite Mills Limited. From the table we can understand that among total production equipments of those factories were 4250 and affected 3050 which were $65.16 \%$ of total equipments and there rate of recovery $11.83 \%$. Net loss of machinery of the observed factories is BDT 11217000000 (Approx.).

Table 4. Losses of Materials.

\begin{tabular}{|c|c|c|c|c|c|c|c|c|c|}
\hline $\begin{array}{l}\text { Name of } \\
\text { Company }\end{array}$ & $\begin{array}{l}\text { Total } \\
\text { Damage Raw } \\
\text { Materials } \\
\text { BDT }\end{array}$ & $\begin{array}{l}\text { Total Raw } \\
\text { Materials } \\
\text { Recovery } \\
\text { BDT }\end{array}$ & $\begin{array}{l}\text { Net Loss of } \\
\text { Raw } \\
\text { Materials } \\
\text { BDT }\end{array}$ & $\begin{array}{l}\text { Total } \\
\text { Damage } \\
\text { Processing } \\
\text { Goods BDT }\end{array}$ & $\begin{array}{l}\text { Total } \\
\text { Processing } \\
\text { Goods } \\
\text { Recovery } \\
\text { BDT }\end{array}$ & $\begin{array}{l}\text { Net Loss of } \\
\text { Processing } \\
\text { Goods BDT }\end{array}$ & $\begin{array}{l}\text { Total } \\
\text { Damage } \\
\text { Finished } \\
\text { Goods BDT }\end{array}$ & $\begin{array}{l}\text { Total } \\
\text { Finished } \\
\text { Goods } \\
\text { Recovery } \\
\text { BDT }\end{array}$ & $\begin{array}{l}\text { Net Loss of } \\
\text { Finished } \\
\text { Goods BDT }\end{array}$ \\
\hline $\begin{array}{l}\text { Tazreen } \\
\text { Fashion }\end{array}$ & $1,00,00,000$ & $20,00,000$ & $80,00,000$ & $50,00,000$ & $10,00,000$ & $40,00,000$ & $5,00,00,000$ & $50,00,000$ & $4,50,00,000$ \\
\hline $\begin{array}{l}\text { Smart } \\
\text { Fashion } \\
\text { Export } \\
\text { Factory }\end{array}$ & $5,00,00,000$ & $15,00,000$ & $4,85,00,000$ & $10,00,000$ & $1,00,000$ & $9,00,000$ & $1,00,00,000$ & $10,00,000$ & $90,00,000$ \\
\hline $\begin{array}{l}\text { Tung Hai } \\
\text { Sweaters } \\
\text { Ltd }\end{array}$ & $1,00,00,000$ & $10,00,000$ & $90,00,000$ & $5,00,00,000$ & $10,00,000$ & $4,90,00,000$ & $5,00,00,000$ & $1,00,00,000$ & $4,00,00,000$ \\
\hline $\begin{array}{l}\text { Aswad } \\
\text { Composite } \\
\text { Mills } \\
\text { Limited }\end{array}$ & $1,00,00,000$ & $15,00,000$ & $85,00,000$ & $50,00,000$ & $10,00,000$ & $40,00,000$ & $2,50,00,000$ & $15,00,000$ & $2,35,00,000$ \\
\hline $\begin{array}{l}\text { Standard } \\
\text { Group }\end{array}$ & $100,00,00,000$ & $10,00,00,000$ & $90,00,00,000$ & $50,00,00,000$ & $1,00,00,000$ & $49,00,00,000$ & $10,00,00,000$ & $10,00,000$ & $9,90,00,000$ \\
\hline $\begin{array}{l}\text { Mega Yarn } \\
\text { Dyeing } \\
\text { Mills } \\
\text { Limited }\end{array}$ & $5,00,000$ & $1,00,000$ & $4,00,000$ & $5,00,000$ & $1,00,000$ & $8,00,000$ & 0 & 0 & $1,00,000$ \\
\hline Total & & & $97,44,00,000$ & & & $54,87,00,000$ & & & $21,66,00,000$ \\
\hline
\end{tabular}

Source: Field Survey 2015 


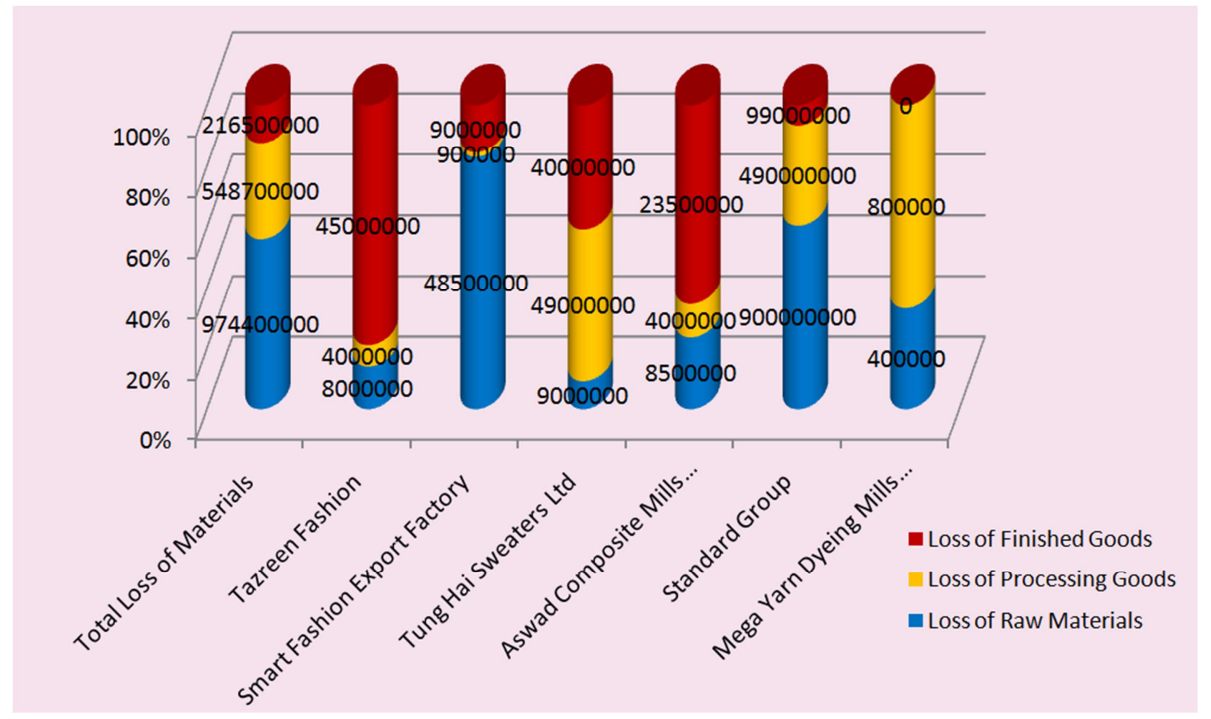

Figure 4. Loss of Materials.

\section{Loss of Materials}

Physical damage and loss of materials refers to the different types of materials or goods (eg. Physical damage to raw materials, products in stock or finished goods, semi finished products etc.). This table refers to the net loss of raw materials of six factories is BDT 974400000 (Approx.), loss of processing or semi finished goods is BDT 548700000 (Approx.) and loss of finished goods is BDT 216600000 (Approx.). The consolidated losses of materials are BDT 1739700000 (Approx.).

Table 5. Loss of Production.

\begin{tabular}{|c|c|c|c|c|c|c|c|}
\hline $\begin{array}{l}\text { Name of } \\
\text { Company }\end{array}$ & $\begin{array}{l}\text { Item of } \\
\text { Productio } \\
n\end{array}$ & $\begin{array}{l}\text { Total } \\
\text { Production } \\
\text { Capacity (Per } \\
\text { Day Pieces) }\end{array}$ & $\begin{array}{l}\text { Total } \\
\text { Production } \\
\text { Loss (Per Day } \\
\text { Pieces) }\end{array}$ & $\begin{array}{l}\text { Total Production Loss } \\
\text { Per Day(BDT) }\end{array}$ & $\begin{array}{l}\text { Factory was } \\
\text { remain closed } \\
\text { till } 31 \text { Oct. } \\
2015 \text { (Days) }\end{array}$ & $\begin{array}{l}\text { Total } \\
\text { Production } \\
\text { Loss (BDT) }\end{array}$ & $\begin{array}{l}\text { Total } \\
\text { Production } \\
\text { Loss } \\
\text { (Average) } \\
\text { BDT }\end{array}$ \\
\hline $\begin{array}{l}\text { Tazreen } \\
\text { Fashion }\end{array}$ & $\begin{array}{ll}\text { 1. } & \text { Knit } \\
\text { Polo } \\
\text { Shirt } \\
\text { 2. } & \text { Fleece } \\
\text { Jacket(f } \\
\text { ancy) } \\
\text { 3. } \text { Basic T } \\
\text { Shirt }\end{array}$ & $\begin{array}{l}\text { 1. Knit Polo } \\
\text { Shirt: } 20,000 \\
\text { 2. Fleece } \\
\text { Jacket(fancy): } \\
10,000 \\
\text { 3. Basic T Shirt: } \\
25,000\end{array}$ & $\begin{array}{l}\text { 1. Knit Polo } \\
\text { Shirt: } 20,000 \\
\text { 2. Fleece } \\
\text { Jacket(fancy } \\
\text { ): } 10,000 \\
\text { 3. Basic Shirt: } \\
25,000\end{array}$ & $\begin{array}{l}\text { Polo Shirt: } 20,000 \times 150= \\
30,00,000 \\
\text { Fleece Jacket: } \\
\text { 10,000X350=35,00,000 } \\
\text { Basic T Shirt: } 25,000 \times 120 \\
=30,00,000\end{array}$ & 1057days & $\begin{array}{l}\text { Polo Shirt: } \\
\text { 317,10,00,000F1 } \\
\text { eeceJacket: } \\
369,95,00,000 \\
\text { Basic Shirt: } \\
317,10,00,000\end{array}$ & $334,71,66,667$ \\
\hline $\begin{array}{l}\text { Smart } \\
\text { Fashion } \\
\text { Export } \\
\text { Factory }\end{array}$ & $\begin{array}{ll}\text { - } & \text { Trousers } \\
& / \text { Pants } \\
\text { - } & \text { Jacket } \\
\text { - } & \text { Basic } \\
& \text { Shirt }\end{array}$ & $\begin{array}{l}\text { 1. Trousers/Pants } \\
: 6500 \\
\text { 2. Jacket: } 3,500 \\
\text { 3. Basic Shirt: } \\
7,000\end{array}$ & $\begin{array}{l}\text { 1. Trousers/Pan } \\
\text { ts: } 6500 \\
\text { 2. Jacket: } 3,500 \\
\text { 3. Basic Shirt: } \\
7,000\end{array}$ & $\begin{array}{l}\text { Trousers/Pants: } \\
6500 \times 250=16,25,000 \\
\text { Jacket: } \\
3,500 \times 350=12,25,000 \\
\text { Basic Shirt: } \\
\text { 7,000X120=8,40,000 }\end{array}$ & 995days & $\begin{array}{l}\text { Trousers/Pants: } \\
\text { 161,68,75,000 } \\
\text { Jacket: } \\
\text { 121,88,75,000 } \\
\text { Basic T-shirt: } \\
83.58,00,000\end{array}$ & $122,38,50,000$ \\
\hline $\begin{array}{l}\text { Tung Hai } \\
\text { Sweaters } \\
\text { Ltd }\end{array}$ & $\begin{array}{l}\text { Knitted } \\
\text { sweaters }\end{array}$ & Knitted sweaters & $\begin{array}{l}\text { Knitted } \\
\text { sweaters: } 65,000\end{array}$ & $\begin{array}{l}\text { Knitted sweaters: } \\
65,000 \times 250=1,62,50,000\end{array}$ & 65days & $\begin{array}{l}\text { Knitted } \\
\text { sweaters: } \\
105,62,50,000\end{array}$ & $105,62,50,000$ \\
\hline $\begin{array}{l}\text { Aswad } \\
\text { Composite } \\
\text { Mills } \\
\text { Limited }\end{array}$ & $\begin{array}{l}\text { Knitted } \\
\text { sweaters }\end{array}$ & $\begin{array}{l}\text { Knitted sweaters: } \\
70,000\end{array}$ & $\begin{array}{l}\text { Knitted } \\
\text { sweaters: } 70,000\end{array}$ & $\begin{array}{l}\text { Knitted sweaters: } \\
70,000 \times 250=1,75,00,000\end{array}$ & 100days & $\begin{array}{l}\text { Knitted } \\
\text { sweaters: } \\
175,00,00,000\end{array}$ & $175,00,00,000$ \\
\hline $\begin{array}{l}\text { Standard } \\
\text { Group }\end{array}$ & $\begin{array}{ll}\text { 1. } & \text { Knit } \\
\text { Polo } \\
\text { Shirt } \\
\text { 2. } & \text { Fleece } \\
\text { Jacket(f } \\
\text { ancy) } \\
\text { 3. } & \text { Basic } \\
\text { Shirt } \\
\text { 4. } & \text { Knitted } \\
\text { sweaters }\end{array}$ & $\begin{array}{l}\text { Knit Polo Shirt: } \\
100000 \\
\text { Fleece } \\
\text { Jacket(fancy): } \\
65,000 \\
\text { Basic Shirt: } \\
1,50,000 \\
\text { Knitted sweaters: } \\
60,000\end{array}$ & $\begin{array}{l}\text { Knit Polo Shirt: } \\
100000 \\
\text { Fleece } \\
\text { Jacket(fancy): } \\
65,000 \\
\text { Basic Shirt: } \\
1,50,000 \\
\text { Knitted } \\
\text { sweaters: } 60,000\end{array}$ & $\begin{array}{l}\text { Jacket: } \\
65000 \times 350=2,27,50,000 \\
\text { Basic Shirt: }\end{array}$ & 692days & $\begin{array}{l}\text { Knit Polo Shirt: } \\
1038,00,00,000\end{array}$ & $1223,97,50,000$ \\
\hline
\end{tabular}




\begin{tabular}{|c|c|c|c|c|c|c|c|}
\hline $\begin{array}{l}\text { Name of } \\
\text { Company }\end{array}$ & $\begin{array}{l}\text { Item of } \\
\text { Productio } \\
\text { n }\end{array}$ & $\begin{array}{l}\text { Total } \\
\text { Production } \\
\text { Capacity (Per } \\
\text { Day Pieces) }\end{array}$ & $\begin{array}{l}\text { Total } \\
\text { Production } \\
\text { Loss (Per Day } \\
\text { Pieces) }\end{array}$ & $\begin{array}{l}\text { Total Production Loss } \\
\text { Per Day(BDT) }\end{array}$ & $\begin{array}{l}\text { Factory was } \\
\text { remain closed } \\
\text { till } 31 \text { Oct. } \\
2015 \text { (Days) }\end{array}$ & $\begin{array}{l}\text { Total } \\
\text { Production } \\
\text { Loss (BDT) }\end{array}$ & $\begin{array}{l}\text { Total } \\
\text { Production } \\
\text { Loss } \\
\text { (Average) } \\
\text { BDT } \\
\end{array}$ \\
\hline \multirow{3}{*}{$\begin{array}{l}\text { Mega Yarn } \\
\text { Dyeing } \\
\text { Mills } \\
\text { Limited }\end{array}$} & \multirow{3}{*}{$\begin{array}{l}\text { Knitted } \\
\text { sweaters }\end{array}$} & \multirow{3}{*}{$\begin{array}{l}\text { Knitted sweaters: } \\
50,000\end{array}$} & \multirow{3}{*}{$\begin{array}{l}\text { Knitted } \\
\text { sweaters: 50,000 }\end{array}$} & $\begin{array}{l}1,50,000 \times 120=1,80,00,000 \\
\text { Knitted sweaters: } \\
60,000 \times 250=1,50,00,000\end{array}$ & & $\begin{array}{l}\text { Knitted } \\
\text { sweaters: } \\
1038,00,00,000\end{array}$ & \\
\hline & & & & $\begin{array}{l}\text { Knitted sweaters: } \\
50,000 \times 250=1,25,00,000\end{array}$ & 45 days & $\begin{array}{l}\text { Knitted } \\
\text { sweaters: } \\
56,25,00,000\end{array}$ & $56,25,00,000$ \\
\hline & & & & Total & 2954 & & 20179516667 \\
\hline
\end{tabular}

Source: Field Survey 2015

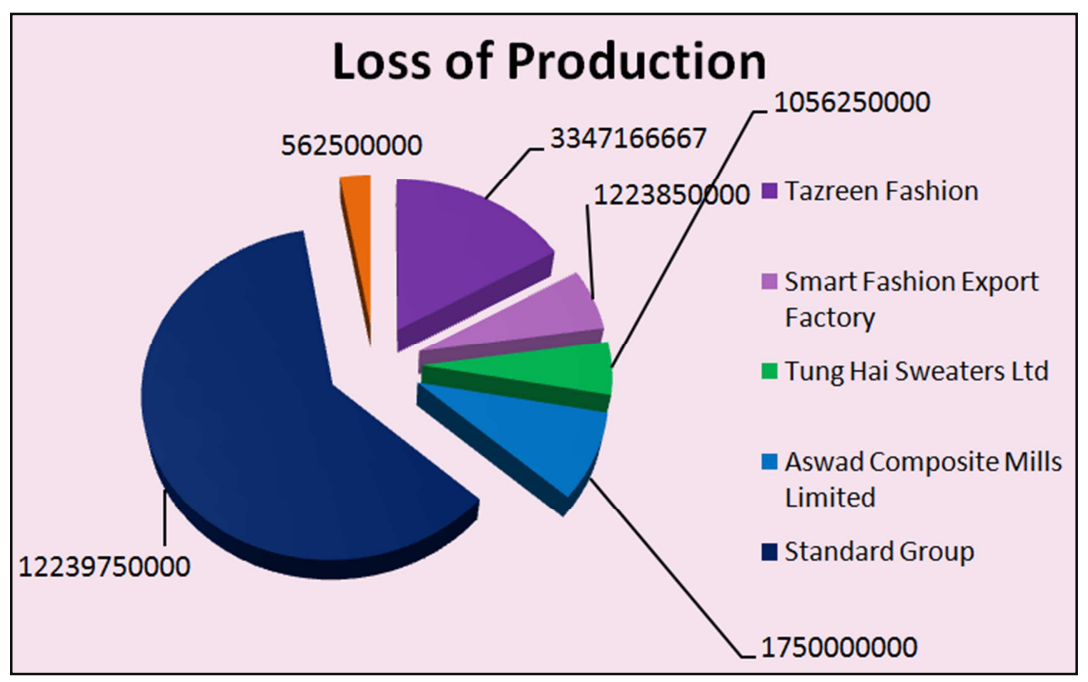

Figure 5. Loss of Production.

\section{Loss of Production}

Remarkable loss has been observed in production sector. Same goods did not produce of those companies. Different products have different cost and different selling prices. In these calculation average minimum prices of different products has been considered. Tazreen Fashion, Smart Fashion and Standard Group have not been run into production and others were remained close for a certain time due to set fire. So, Production loss has been calculated how many days have been closed from the date of occurrence to $31^{\text {st }}$ of October, 2015. Specifically production loss of different companies has been shown in the table and chart also. And the table shows that total loss of production of the six companies BDT 20179516667 (Approx.) against period of 2954 days.

Table 6. Loss Scenario.

\begin{tabular}{|c|c|c|c|c|c|c|c|c|}
\hline $\begin{array}{l}\text { Name of } \\
\text { Company }\end{array}$ & $\begin{array}{l}\text { Net Loss of } \\
\text { Infrastructure } \\
\text { (BDT) }\end{array}$ & $\begin{array}{l}\text { Net Loss of } \\
\text { Machinery } \\
\text { (BDT) }\end{array}$ & $\begin{array}{l}\text { Net Loss of } \\
\text { Raw } \\
\text { Materials } \\
\text { BDT }\end{array}$ & $\begin{array}{l}\text { Net Loss of } \\
\text { Processing } \\
\text { Goods BDT }\end{array}$ & $\begin{array}{l}\text { Net Loss of } \\
\text { Finished } \\
\text { Goods BDT }\end{array}$ & $\begin{array}{l}\text { Total } \\
\text { Production } \\
\text { Loss (Average) }\end{array}$ & $\begin{array}{l}\text { Getting Insurance } \\
\text { Facilities of a } \\
\text { Company from } \\
\text { Insurance Co. }\end{array}$ & $\begin{array}{l}\text { Total Loss of } \\
\text { the Company } \\
\text { (Approximate } \\
\text { ) BDT }\end{array}$ \\
\hline $\begin{array}{l}\text { Tazreen } \\
\text { Fashion } \\
\text { Smart Fashion }\end{array}$ & 450000000 & 1800000000 & 8000000 & 4000000 & 45000000 & 3347166667 & 0 & 5654166667 \\
\hline $\begin{array}{l}\text { Export } \\
\text { Factory }\end{array}$ & 4000000 & 9500000 & 48500000 & 900000 & 9000000 & 1223850000 & 0 & 1295750000 \\
\hline $\begin{array}{l}\text { Tung Hai } \\
\text { Sweaters Ltd }\end{array}$ & 95000000 & 1950000000 & 9000000 & 49000000 & 40000000 & 1056250000 & 1200000000 & 1999250000 \\
\hline $\begin{array}{l}\text { Aswad } \\
\text { Composite } \\
\text { Mills Limited }\end{array}$ & 950000000 & 995000000 & 8500000 & 4000000 & 23500000 & 1750000000 & 1479506490 & 2251493510 \\
\hline $\begin{array}{l}\text { Standard } \\
\text { Group }\end{array}$ & 2250000000 & 6300000000 & 900000000 & 490000000 & 99000000 & 12239750000 & 3000000000 & 19278750000 \\
\hline $\begin{array}{l}\text { Mega Yarn } \\
\text { Dyeing Mills } \\
\text { Limited }\end{array}$ & 5000000 & 162500000 & 400000 & 800000 & 100000 & 562500000 & 100000000 & 631300000 \\
\hline Total & 3754000000 & 11217000000 & 974400000 & 548700000 & 216600000 & 20179516667 & 5779506490 & 31110710177 \\
\hline
\end{tabular}

Source: Field Survey 2015 


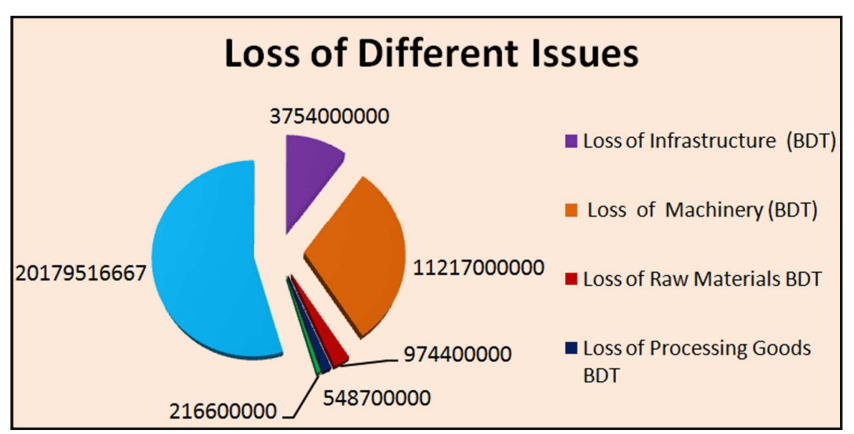

Figure 6. Loss of Different Issues.

Table 7. Scenario of Affected Employee.

\begin{tabular}{|c|c|c|c|c|}
\hline $\begin{array}{l}\text { Name of } \\
\text { Company }\end{array}$ & $\begin{array}{l}\text { Total } \\
\text { Workers }\end{array}$ & Death\% & Injured\% & Jobless \\
\hline $\begin{array}{l}\text { Tazreen } \\
\text { Fashion }\end{array}$ & 1400 & $7.92 \%$ & $21.42 \%$ & $50 \%$ \\
\hline $\begin{array}{l}\text { Smart } \\
\text { Fashion } \\
\text { Export } \\
\text { Factory }\end{array}$ & 450 & $2.22 \%$ & $7.77 \%$ & $88.88 \%$ \\
\hline $\begin{array}{l}\text { Tung Hai } \\
\text { Sweaters } \\
\text { Ltd } \\
\text { Aswad }\end{array}$ & 2700 & $0.30 \%$ & $0.11 \%$ & $0 \%$ \\
\hline $\begin{array}{l}\text { Composite } \\
\text { Mills } \\
\text { Limited }\end{array}$ & 2550 & $0 \%$ & $0 \%$ & $78.43 \%$ \\
\hline $\begin{array}{l}\text { Standard } \\
\text { Group } \\
\text { Mega Yarn }\end{array}$ & 25000 & $0 \%$ & $0 \%$ & $80 \%$ \\
\hline $\begin{array}{l}\text { Dyeing } \\
\text { Mills } \\
\text { Limited }\end{array}$ & 500 & $0.20 \%$ & $0.80 \%$ & $0 \%$ \\
\hline Total & 32600 & $1.77 \%$ (Avg.) & $5.02 \%$ (Avg.) & $49.55 \%$ (Avg.) \\
\hline
\end{tabular}

Source: Field Survey 2015

Loss Scenario

When a factory affects by setting fire, different types of losses are observed. To calculate the overall losses of the factory, loss of different sectors is accumulated. The table shows that loss of six factories consolidated BDT 31110710177 (Approx.) which refers. 45\% of our GDP of 2015. In this case to calculate their loss getting insurance coverage from the insurance company has been subtracted here. By comparing with the different losses, loss of production symbolized the highest amount of all losses which is BDT 20179516667.

This below table shows that the highest employee death $7.92 \%$ and injury is also recorded $21.42 \%$ in Tazreen Fashion. Highest jobless $88.88 \%$ in Smart Fashion Export Factory. So far we know after the incident Smart Fashion being remain closed. So, the employee of that garment became jobless. The second highest jobless situation holds Standard Group $80 \%$. Mainly this factory is victimized by the sabotage and the incident occurred at midnight so, most of the sectors of this factory destroyed and it has not run in production yet. From this table we can see that there was no death and injury in Standard Group fire but the amount of jobless is very high. From the six incidents $49.55 \%$ employee being jobless among 32600 employees in spite of $0 \%$ jobless condition in Tung Hai Sweaters Ltd and Mega Yarn Dyeing Mills Limited.

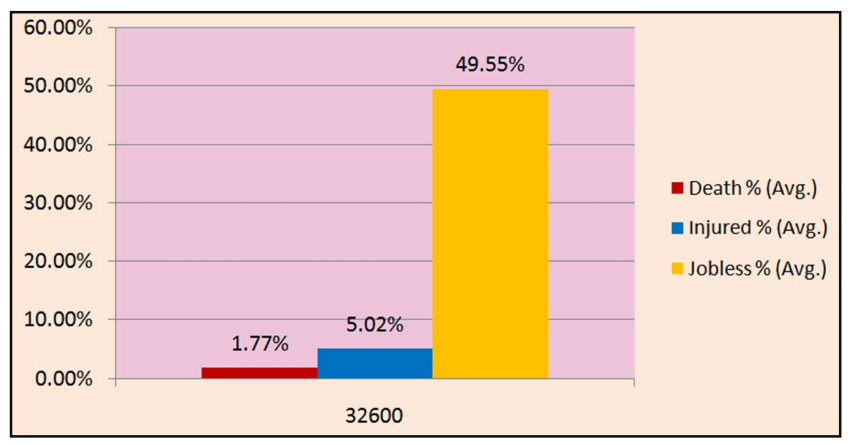

Figure 7. Status of the Employee.

Table 8. Valuation of the Employee.

\begin{tabular}{|c|c|c|c|c|c|c|c|c|}
\hline $\begin{array}{l}\text { Name of } \\
\text { Company }\end{array}$ & $\begin{array}{l}\text { Death } \\
\text { Person }\end{array}$ & $\begin{array}{l}\text { Considering Value } \\
\text { of a Death Person } \\
(18-60) \text { Years BDT } \\
=(6000 \text { WD x 500 } \\
\text { SPD) }\end{array}$ & $\begin{array}{l}\text { Total Value } \\
\text { Of Death } \\
\text { Persons (18- } \\
\text { 60) Years } \\
\text { BDT } \\
\end{array}$ & $\begin{array}{l}\text { Injured } \\
\text { Person }\end{array}$ & $\begin{array}{l}\text { Total Cost of Injured } \\
\text { Persons for } 30 \text { Days. } \\
\text { If their treatment } \\
\text { cost Considered BDT } \\
5000 \text { per day }\end{array}$ & $\begin{array}{l}\text { Number } \\
\text { of } \\
\text { Disabled } \\
\text { Person }\end{array}$ & $\begin{array}{l}\text { Cost of a } \\
\text { Disabled Person } \\
(18-60) \text { Years }= \\
6000 \text { WD x (500 } \\
\text { SPD+350TC) } \\
\end{array}$ & $\begin{array}{l}\text { Total Value of } \\
\text { Disabled } \\
\text { Persons (18- } \\
\text { 60) Years }\end{array}$ \\
\hline Tazreen Fashion & 111 & $30,00,000$ & $33,30,00,000$ & 300 & $45,00,000$ & 10 & $51,00,000$ & $5,10,00,000$ \\
\hline $\begin{array}{l}\text { Smart Fashion } \\
\text { Export Factory }\end{array}$ & 10 & $30,00,000$ & $3,00,00,000$ & 35 & $5,25,000$ & 4 & $51,00,000$ & $2,04,00,000$ \\
\hline $\begin{array}{l}\text { Tung Hai Sweaters } \\
\text { Ltd }\end{array}$ & 08 & $30,00,000$ & $2,40,00,000$ & 03 & 45,000 & 0 & $51,00,000$ & 0 \\
\hline $\begin{array}{l}\text { Aswad Composite } \\
\text { Mills Limited }\end{array}$ & 10 & $30,00,000$ & $3,00,00,000$ & 50 & $7,50,000$ & 2 & $51,00,000$ & $1,02,00,000$ \\
\hline Standard Group & 0 & $30,00,000$ & 0 & 0 & 0 & 0 & $51,00,000$ & 0 \\
\hline $\begin{array}{l}\text { Mega Yarn Dyeing } \\
\text { Mills Limited }\end{array}$ & 01 & $30,00,000$ & $30,00,000$ & 04 & 60,000 & 0 & $51,00,000$ & 0 \\
\hline Total & 140 & & $42,00,00,000$ & 392 & $58,80,000$ & 16 & & $8,16,00,000$ \\
\hline
\end{tabular}

Source: Field Survey 2015

\section{Valuation of the Employee}

In this table indicates the size of death 140, injured 392 and number of disability is 16 among the injured people. In spite of having been the quantity of death and injured person nil in the occurrence of Standard Group the quantity of death and injury are not so little. Valuation of death, injured and disabled person is very difficult and it's never be measured accurately but different methodology have been used here to 
calculate the value of loss of life, injury and disability. Generally the value of death person has been considered more than the injured and disable person but here the value of injured and disable person considered higher than that of death because their living cost, treatment cost, family expenditure and inflation should be considered. To calculate the value of a death person 600 working days (WD) multiplied by 500 as per day salary (SPD) has been considered and in context of disable person, the product of 600 working days multiplies by $(500+350)$ in which indicates salary per day plus treatment cost (TC) has been considered for valuation of a person with disability. According to the calculation the value of a death person measured BDT 3000000 and a disabled person BDT 5100000. And the value of injured person is measured in consideration of per day treatment cost BDT 5000 multiplied by 30 days because of their expenditure has been considered for one month. By this calculation total value of mentioned death persons is BDT 420000000 and a disabled person is BDT 81600000 .

Table 9. Providing Insurance Facilities.

\begin{tabular}{|c|c|c|c|c|c|c|}
\hline Name of Company & Death Person & $\begin{array}{l}\text { Insurance Facilities } \\
\text { got per Death Worker }\end{array}$ & $\begin{array}{l}\text { Number of Death } \\
\text { Workers got }\end{array}$ & $\begin{array}{l}\text { Total Amount } \\
\text { Received by Death } \\
\text { Workers }\end{array}$ & $\begin{array}{l}\text { Death } \\
\text { Workers got } \\
(\%) \\
\end{array}$ & Injured \\
\hline Tazreen Fashion & 111 & $1,00,000$ & 20 & $20,00,000$ & $18.01 \%$ & 300 \\
\hline $\begin{array}{l}\text { Smart Fashion Export } \\
\text { Factory }\end{array}$ & 10 & 0 & 0 & 0 & $0 \%$ & 35 \\
\hline Tung Hai Sweaters Ltd & 08 & $7,00,000$ & 8 & $56,00,000$ & $100 \%$ & 03 \\
\hline $\begin{array}{l}\text { Aswad Composite } \\
\text { Mills Limited }\end{array}$ & 10 & $2,00,000$ & 7 & $14,00,000$ & $70 \%$ & 50 \\
\hline Standard Group & 0 & 0 & 0 & 0 & $0 \%$ & 0 \\
\hline $\begin{array}{l}\text { Mega Yarn Dyeing } \\
\text { Mills Limited }\end{array}$ & 01 & $3,00,000$ & 1 & $3,00,000$ & $100 \%$ & 04 \\
\hline Total & 140 & & 46 & $93,00,000$ & $32.86 \%$ & 392 \\
\hline
\end{tabular}

Table 9. Continued.

\begin{tabular}{|c|c|c|c|c|c|}
\hline Name of Company & $\begin{array}{l}\text { Insurance Facilities } \\
\text { got per Injured } \\
\text { Worker } \\
\end{array}$ & $\begin{array}{l}\text { Number of } \\
\text { Injured Workers } \\
\text { got }\end{array}$ & $\begin{array}{l}\text { Injured Workers } \\
\text { got }(\%)\end{array}$ & $\begin{array}{l}\text { Total Amount Received } \\
\text { by Injured Workers }\end{array}$ & $\begin{array}{l}\text { Getting Insurance Facilities } \\
\text { of a Company from } \\
\text { Insurance Co. }\end{array}$ \\
\hline Tazreen Fashion & 0 & 0 & $0 \%$ & 0 & 0 \\
\hline $\begin{array}{l}\text { Smart Fashion Export } \\
\text { Factory }\end{array}$ & 0 & 0 & $0 \%$ & 0 & 0 \\
\hline Tung Hai Sweaters Ltd & 200000 & 03 & $100 \%$ & 600000 & $120,00,00,000$ \\
\hline $\begin{array}{l}\text { Aswad Composite } \\
\text { Mills Limited }\end{array}$ & 50000 & 50 & $100 \%$ & 2500000 & $147,95,06,490$ \\
\hline Standard Group & 0 & 0 & $0 \%$ & 0 & $300,00,00,000$ \\
\hline $\begin{array}{l}\text { Mega Yarn Dyeing } \\
\text { Mills Limited }\end{array}$ & 50000 & 04 & $100 \%$ & 200000 & $10,00,00,000$ \\
\hline Total & & 57 & $14.54 \%$ & $33,00,000$ & 4699506490 \\
\hline
\end{tabular}

Source: Field Survey 2015

\section{Insurance Facilities}

Most of the employees in different sectors are not awarded of their lives and insurance because of their darkness and illiteracy. So, they are being deprived frequently in their life. In this table refers that 46 employees among 140 death employees which indicates $32.86 \%$ and 57 of 392 injured employees refers $14.54 \%$ have got providing insurance facility as they are enlisted employee of a fire accidental insurance coverage.

Table 10. Compensation, Treatment and other Facilities Provided by the Government, Company \& BGMEA.




Table 10. Continued.

\begin{tabular}{lllllll}
\hline $\begin{array}{l}\text { Name of } \\
\text { Company }\end{array}$ & Injured & $\begin{array}{l}\text { Govt./BGMEA/Compa } \\
\text { ny Subsidy Per Injured } \\
\text { Person }\end{array}$ & $\begin{array}{l}\text { Number of } \\
\text { Injured Workers } \\
\text { got }\end{array}$ & $\begin{array}{l}\text { Total Amount } \\
\text { Received by } \\
\text { Injured Workers }\end{array}$ & $\begin{array}{l}\text { Total Amount } \\
\text { Received by Death } \\
\text { Workers (\%) }\end{array}$ & $\begin{array}{l}\text { Total Amount } \\
\text { Received by Injured } \\
\text { Workers(\%) }\end{array}$ \\
\hline $\begin{array}{l}\text { Tazreen Fashion } \\
\text { Smart Fashion }\end{array}$ & 300 & $1,00,000$ & 63 & $63,00,000$ & $38.74 \%$ & $21 \%$ \\
$\begin{array}{l}\text { Export Factory } \\
\text { Tung Hai }\end{array}$ & 35 & 10000 & 35 & $35,00,000$ & $100 \%$ & $100 \%$ \\
$\begin{array}{l}\text { Sweaters Ltd } \\
\text { Aswad }\end{array}$ & 03 & 0 & 0 & 0 & $0 \%$ & $0 \%$ \\
$\begin{array}{l}\text { Composite Mills } \\
\text { Limited }\end{array}$ & 50 & 0 & 0 & 0 & $100 \%$ & $0 \%$ \\
$\begin{array}{l}\text { Standard Group } \\
\text { Mega Yarn }\end{array}$ & 0 & 0 & 0 & 0 & $0 \%$ & $0 \%$ \\
$\begin{array}{l}\text { Dyeing Mills } \\
\text { Limited }\end{array}$ & 04 & 0 & 0 & 0 & $100 \%$ & $0 \%$ \\
Total & 392 & & 98 & 9800000 & $56.45 \%$ \\
\hline
\end{tabular}

Source: Field Survey 2015

\section{Compensation for Treatment, Funeral and other Facilities}

Different types of compensation and facilities had been provided to the death and injured persons by the government authority, BGMEA, their own company and other organization as far I know 63 death persons got subsidy of Government, BGMEA, their own company or other organizations and 11 death workers got funeral facility among 140 s that refers $56.45 \%$ of total death and their receiving amount BDT 41820000. On the other hand $20.16 \%$ of injured person got treatment facility of government authority and BGMEA. Mainly among six incidents fire on Tazreen Fashion and Smart Fashion Export Factory were very fatal accidents and magnitude of their death and injury were very high. In this context government and BGMEA became very much concern and tried to provide facilities.

Table 11. Loss of Fire Fighting Units.

\begin{tabular}{|c|c|c|c|c|c|}
\hline Name of Company & Time of Occurrence & $\begin{array}{l}\text { Duration of } \\
\text { Control (Hours) }\end{array}$ & $\begin{array}{l}\text { Number of Fire } \\
\text { Service Units Works }\end{array}$ & $\begin{array}{l}\text { Cost per Unit per Hour } \\
\text { (Approximately) BDT }\end{array}$ & $\begin{array}{l}\text { Total Service Cost of the } \\
\text { Fire Service Units BDT }\end{array}$ \\
\hline Tazreen Fashion & 6: $00 \mathrm{pm}-6: 00 \mathrm{am}$ & 11 & 10 & 6000 & 660000 \\
\hline $\begin{array}{l}\text { Smart Fashion Export } \\
\text { Factory }\end{array}$ & $2: 30 \mathrm{pm}-3: 15 \mathrm{pm}$ & 1 & 9 & 6000 & 54000 \\
\hline $\begin{array}{l}\text { Tung Hai Sweaters } \\
\text { Ltd }\end{array}$ & 11: $00 \mathrm{pm}-12: 45 \mathrm{am}$ & 2 & 13 & 6000 & 156000 \\
\hline $\begin{array}{l}\text { Aswad Composite } \\
\text { Mills Limited }\end{array}$ & 6: $00 \mathrm{pm}-4: 00 \mathrm{am}$ & 10 & 9 & 6000 & 540000 \\
\hline Standard Group & 12: $00 \mathrm{am}-3: 00 \mathrm{pm}$ & 15 & 22 & 6000 & 1980000 \\
\hline $\begin{array}{l}\text { Mega Yarn Dyeing } \\
\text { Mills Limited }\end{array}$ & 3: $35 \mathrm{am}-8: 00 \mathrm{am}$ & 5 & 11 & 6000 & 330000 \\
\hline Total & & 44 & 74 & & $37,20,000$ \\
\hline
\end{tabular}

Source: Field Survey 2015

\section{Loss of Fire Extinguishers}

The expenses of fire protection team, in order to prevent industrial fire, within a certain period from which the cost of per unit area can be estimated according to destroyed or damaged area. The cost of per unit multiplied by cost of per hour is the loss of fire protection expenses. Mostly this loss is generally ignored because it is considered as a duty of government and for this every year an immense loss has to be incurred for this purpose. From the table we can identify that from the six incidents 74 fire extinguisher units takes 44 hours to the control of fire and its approximate cost BDT 3720000 . If the cost of every year's fire extinguishing is visualized it will not so little as govt. expenditure.

Biological Economic Loss/loss on ecosystem

It is very difficult to estimate accurately the loss on the biological environment caused by industrial fire. Considering the current situations and possibilities, estimate only three kinds of loss, i.e. economic loss on agricultural production, economic loss on ecosystem and loss of wildlife are not possible. For the time being, it will be added and perfected by further research and practice.

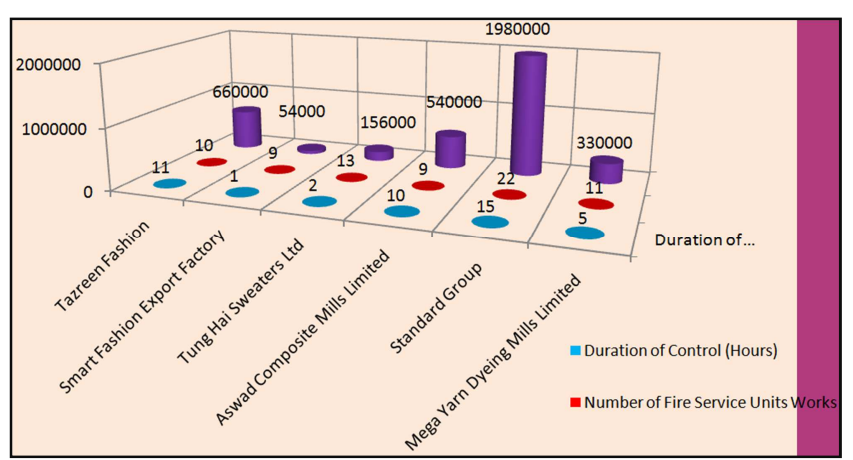

Figure 8. Loss of Fire Fighting Units.

Loss of Image 
In Bangladesh, fire in garments factory causes huge loss every year. Mainly the damage and loss have been calculated as direct loss like loss of infrastructure, loss of machinery, loss of production, loss of materials etc. But there have several indirect losses which do not be calculated. Loss of image is a kind of indirect loss there has an intrinsic value which is often avoided. In case of fire Bangladesh RMG sector faces different obstacles. Due to lack of work place safety Bangladesh lost GSP facility from the USA. And for the fire incidents many buyers cancel their contract with the affected garments which creates deprivation to earn foreign currency. In this study cannot calculate how much money lost Bangladesh due to loss of image for fire because of limitation of time and opportunity. Furthermore the government of Bangladesh and the owners of the garment factory should take initiatives for this purpose.

Expenses of Dealing with Aftermath:

Different types of secondary losses mainly intangible losses (death, injured, equipment and resources expended to relief, persons with disability, clean up cost, repair cost etc.) which are often avoided and unestimated. Due to limitation of time, lack of logistic and financial support, the mentioned issues could not identify. In this study BDT 3000000 for the death person and BDT 5100000 have been considered for the disabled person as their value of life. Mainly the value of life of a dead person is considered high but I have tried to the value of life of a disabled person is high because he loses his earning capacity and expenditure of medicine is added with this. Besides this social and psychological pain are not measured by money.

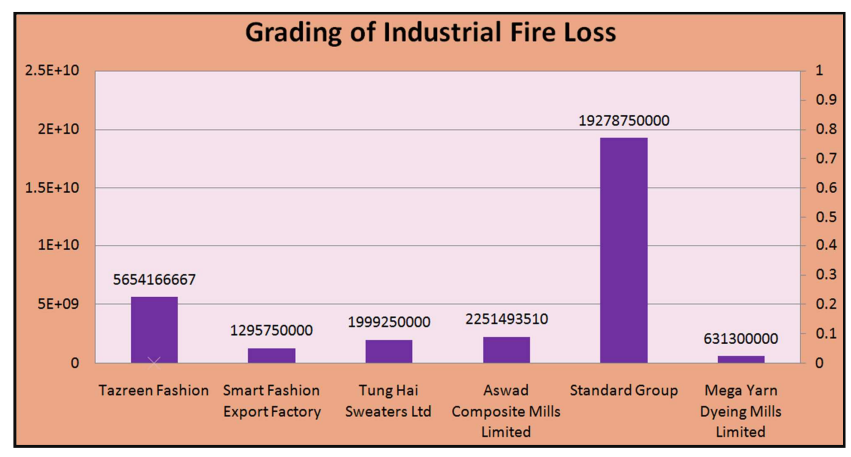

Figure 9. Grading of Industrial Fire Loss.

\section{Grading of Industrial Fire Loss}

On regards to the relevant standards of Bangladesh, fires on RMG sectors are graded into three classes on the basis of the amount lost in resources, property and personnel death and wound caused by one industrial fire:

Class I: Extraordinarily serious industrial fire, the loss of it is more than BDT 100 crore;

Class II: Serious industrial fire, the loss of it is between BDT 50 crore - 100 crore;

Class III: Ordinary industrial fire, the loss of it is less than BDT 50 crore.

According to the above mentioned categories, there were no Class III types of losses. The figure shows that only Mega Yarn Dyeing Mills Limited implies Class II category loss because its loss BDT 630000000 and all the losses are Class I category because their loss more than BDT 100 crore.

\section{Findings and Recommendation}

Key Findings: Findings from different issues are given bellow:

\subsection{Causes of Fire}

Seventy two fire incidents of garments and textile factory fire have been observed and by those the following causes are identified:

- Electric short circuit

- Mechanical glitch of power generation

- Boiler explosion

- Sparking of fluorescent light

- Iron explosion

- Sparked from machine

- Sparkling from workshop

- Cigarettes or match sticks

- Sabotage

- Unknown

\subsection{Causes of Death and Injury}

- The emergency exits were locked and the workers could not escape

- Lack of emergency exits

- Size of emergency exits is narrow

- The stairway was dark and full of smoke

- The garment workers were stepping down from the factory following fire panic

- Falling from the staircase

- False fire alarm and creating panic

- During fire broke out the workers were sleeping

- Fire alarm created panic and many workers jumped out of the upper floor

- The stairway was dark and full of smoke and the electricity supply had been shut down and many were death for suffocation.

\subsection{Existing Fire Safety Issues}

- Most of the factories there were no sufficient water sources inside or outside.

- At present the new generation factories have owned high technology for fire safety.

- There are lack of transport facility mainly the route to enter fire service convoy is very poor in the industrial areas like Gazipur, Savar, Tongi adjacent to the Dhaka city.

- All most all of the factories hang the number of nearby Fire Service and Civil Defence.

- Majority of the factories conduct fire drill.

- There is found fire or emergency exit or stairways in every factory.

\subsection{Present Condition of the Newly Established Factories}

- The Bangladesh Accord Group created by retailers from the European Union and the Alliance of North American buyers evaluate compliance issues in Bangladesh's readymade garment industry. According to their evaluating report there has a significant change in the RMG sector of Bangladesh. 
- Most of the owner of the factories has followed to the building code, fire safety issue, labour law of ILO and Bangladesh etc.

- But a remarkable issue which is a matter of concern for the workers like insurance facility is neglected. And for this most of the fire affected workers are being deprived to get insurance coverage.

\subsection{Recommendation}

- Owner of the factory should give remarkably importance in electric supply line, wearing cables and electrical equipments.

- Separation of store house from the factory is needed

- All the factories should have wide emergency exits and have an appointed maintenance man who has trained and conscious.

- Awareness building to the employees is very necessary.

- Government should formulate and implement Occupational Safety and Health (OSH) Policy on priority basis

- Properly implement Bangladesh Labour Law and other relevant laws in all factories

- Increase the capacity (manpower \& logistic) of Department of Inspection for Factories \& establishment and introduce separate inspection system for RMG sector.

- Government should take steps to operate mobile courts in factory level regularly to ensure occupational safety $\&$ health.

- Every factory owners should establish building properly following the Bangladesh National Building Code and fire safety guideline.

- Arrange fire safety and OSH training regularly including refreshers training. Also arrange effective fire drill regularly.

- Ensure availability of fire defense materials in each floor of the establishment and use of it when needed.

- Use separate establishment for warehouse \& production unit.

- Roof top and all gates of the factory where workers movement exist are remain open during working hour employing adequate number of security guards in each gate.

- Develop a separate RMG Workers Welfare Fund with the contribution of concern employers association, buyers, brands, workers and government to ensure social security of the workers.

- Every factory should have a research wing which will maintain connection with the academic institution because of identifying their problems and the way of solving.

\section{Conclusion}

Starting from scratch, Bangladesh has come a long way and is now one of 10 new emerging countries in the world. The macroeconomic stability, 6\% annual average GDP growth, robust performance of remittance and export, strong foreign currency reserve, and remarkable social and human development over the past decade - all reflect our underlying strengths.

According to the study, the US-based fashion companies are expected to boost their sourcing from Bangladesh in the next two years. McKinsey, a global management consulting firm, described Bangladesh as the next hot spot in apparel sourcing. The renowned firm forecasts export-value growth of 7-9\% annually and our apparel export will double by 2015 and nearly triple by 2020 provided that we can successfully overcome a few challenges including developing infrastructure and skill workforce.

Fire occurrences in the garment sectors are very sever. During last 25 years there was heavy lose for fire accidents. So, prepared to control all the activities in the garments sectors are needed. Most of the fire hazards in RMG sector occurs causing electric short circuit in Bangladesh. And this occurrence creates huge economic damage and loss in this sector. In order to attach of the store house or godown with the factory it becomes impossible to out let of the goods from the store house which happens great loss. Distance of fire station is another reason to control of fire. Locked and narrow emergency exits, panic, dark stairway, full of smoke and the electricity supply been shut down and suffocation for the smoke are the main reasons for death and casualty in the garments factories in our country. For this due to lessening the damage and loss in addition with death and injury government and the owner of the factories do follow the additional guidelines of this study would be betterment in our RMG sector.

It is the responsibility of all of us to protect the interest of this industry which has given our economy a strong footing, created jobs for millions of people, especially for women, lifted them from the abyss of chronic poverty and given them a dignified life. Now what we need to do is deal with all the challenges facing our garment industry, paving the way for its further development.

\section{Annexure: 1 (Interview Questionnaire)}

Table 12. Information about Responder.

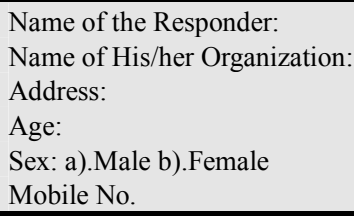

Table 13. Information about industry (Part-I).

\begin{tabular}{|c|c|c|c|}
\hline \multirow[t]{2}{*}{ Sl.No. } & \multirow[t]{2}{*}{ Questionnaire } & \multicolumn{2}{|c|}{$\sqrt{ }$ Mark } \\
\hline & & Yes & No \\
\hline 01. & Does the factory have any fire protection system? & & \\
\hline 02. & $\begin{array}{l}\text { Do the employees enjoy any insurance policy } \\
\text { provided by the factory? }\end{array}$ & & \\
\hline 03. & $\begin{array}{l}\text { Does the factory have any exit stairs during } \\
\text { emergency? }\end{array}$ & & \\
\hline 04. & $\begin{array}{l}\text { Does the factory have any fire control gas } \\
\text { cylinders? }\end{array}$ & & \\
\hline 05. & Is the number of cylinder sufficient? & & \\
\hline 06. & Are the employees aware of fire alarm? & & \\
\hline 07. & Is the fire drill conducted regularly? & & \\
\hline 08. & $\begin{array}{l}\text { Are all fire extinguishers and fire fighting } \\
\text { equipments in good working condition? }\end{array}$ & & \\
\hline
\end{tabular}




\begin{tabular}{lll}
\hline Sl.No. & Questionnaire & $\sqrt{ }$ Mark \\
\hline & & Yes $\quad$ No \\
\hline 09. & $\begin{array}{l}\text { Are all fire extinguishers visible and within } \\
\text { reasonable distance? }\end{array}$ \\
10. & $\begin{array}{l}\text { Are all emergency exits unlocked and } \\
\text { unobstructed? }\end{array}$ \\
$11 . \quad$ & $\begin{array}{l}\text { Does the factory have at least 2 (two) emergency } \\
\text { exits on and opposite sides? }\end{array}$ \\
12. & Is the plan for evacuation of employees illustrated? \\
13. & $\begin{array}{l}\text { Are the emergency phone numbers known to all? } \\
\text { Does the main power supply have visual isolators? }\end{array}$ \\
15. & $\begin{array}{l}\text { Is the main power supply clearly identified and } \\
\text { easy to access? }\end{array}$ \\
\hline
\end{tabular}

Table 14. Information about industry (Part-II).

\begin{tabular}{|c|c|c|}
\hline $\begin{array}{l}\text { SI } \\
\text { No. }\end{array}$ & Questionnaire & Remarks \\
\hline \multirow{4}{*}{01.} & What is the type of this factory? & \\
\hline & a).Knit & \\
\hline & b).Oven & \\
\hline & c).Sweater & \\
\hline 02. & Category of the factory & \\
\hline \multirow[b]{2}{*}{03.} & Man Power: & \\
\hline & Male & \\
\hline \multirow{5}{*}{04.} & Female & \\
\hline & Total Machinery: & \\
\hline & Sewing & \\
\hline & Knitting & \\
\hline & Linking & \\
\hline 05. & Is the factory owned any bank loan? & \\
\hline 06. & If is owned bank loan amount of that. & \\
\hline \multirow{3}{*}{07.} & Name of Bank with Bank Support: & \\
\hline & a). Govt. & \\
\hline & b). Private & \\
\hline 08. & L/C Limit: & \\
\hline \multirow{3}{*}{09.} & Production Capacity (Per day/ Per hour): & \\
\hline & Per Hour: & \\
\hline & Per Day & \\
\hline \multirow{4}{*}{10.} & Salary Expenditure: & \\
\hline & Per Hour: & \\
\hline & Per Day: & \\
\hline & Per Month: & \\
\hline 11. & Is the factory under the coverage of fire insurance? & \\
\hline \multirow{4}{*}{12.} & Insurance Coverage: (Who enjoy this facility?) & \\
\hline & All the employees? No. & \\
\hline & Second grade officers ?No. & \\
\hline & First grade officers? No. & \\
\hline \multirow{4}{*}{13.} & $\begin{array}{l}\text { How many losses may happen if it remains close } \\
\text { for? }\end{array}$ & \\
\hline & An hour (In amount) & \\
\hline & A day (In amount) & \\
\hline & A month(In amount) & \\
\hline
\end{tabular}

Table 15. Information about industry (Part-III).

\begin{tabular}{lll}
\hline SI No. & Questionnaire & Remarks \\
\hline 01. & Is this space rented? \\
02. & If it is rented amount of rent (monthly)? \\
03. & Factory area ? \\
04. & What is the reason of fire? \\
& What percent of the factory is affected? \\
05. & Nonreparable(Lost) \\
& Reparable(Damage) \\
& How many types of machinery are affected by fire? \\
& And approximate price? \\
\hline
\end{tabular}

\begin{tabular}{|c|c|c|}
\hline SI No. & Questionnaire & Remarks \\
\hline \multirow{7}{*}{07.} & Knitting & \\
\hline & Linking & \\
\hline & Approximate Loss & \\
\hline & Finished Goods & \\
\hline & Under processing & \\
\hline & Raw materials & \\
\hline & Number of casualties: & \\
\hline \multirow{3}{*}{08.} & Death & \\
\hline & Wounded: & \\
\hline & Curable & \\
\hline \multirow{4}{*}{09.} & Incurable & \\
\hline & How many employees lost their job? & \\
\hline & Male & \\
\hline & Female & \\
\hline \multirow{4}{*}{10.} & Total number of purchasing order affected: & \\
\hline & Placed orders & \\
\hline & Potential orders & \\
\hline & Loss of Image & \\
\hline \multirow[t]{2}{*}{11.} & Amount of present investment(In taka) & \\
\hline & Loss of production & \\
\hline \multirow{3}{*}{12.} & Per hour & \\
\hline & Per day & \\
\hline & Per month & \\
\hline 13. & Present market value of a product & \\
\hline 14. & $\begin{array}{l}\text { What is the type of environmental degradation } \\
\text { causing fire? }\end{array}$ & \\
\hline 15. & Which are the weaknesses of the factory about fire? & \\
\hline 16. & $\begin{array}{l}\text { Which are the challenges of the factory on } \\
\text { production? }\end{array}$ & \\
\hline 17. & Recommendations on mitigation of fire & \\
\hline
\end{tabular}

\section{References}

[1] Hiete Michael and Merz Mirjam (2009), An Indicator Framework to Assess the Vulnerability of Industrial Sectors against Indirect Disaster Losses, Proceedings of the 6th International ISCRAM Conference - Gothenburg, Sweden, J. Landgren and S. Jul, eds.

[2] Andersson Petra (1997), Evaluation And Mitigation Of Industrial Fire Hazards, Report TVBB-1015,ISRN LUTVDG/TVBB-SE.

[3] Jonkman S.N., P.H.A.J.M. Van Gelder And J.K. Vrijling (2002), An Overview Of Quantitative Risk Measures For Loss Of Life And Economic Damage, Journal Of Hazardous Materials A99, 1-30.

[4] Fanwen Kong (1992), On Estimating Methods Of Economic Losses Of Forest Fire, (Research Institute Of Forestry Economics, Chiuese Academy Of Forestry Sciences, Andingmenwai, Beijing, 100029).

[5] Gao Lan (Beijing Forestry University, Xiaozhang, Haidian District, Beijing, 100083).

[6] Anand Sudhir and Hanson Kara (1997), Disability-adjusted life years: a critical review. Journal of Health Economics 16 (1997) 685-702.

[7] Korteweg Arthur (2007), The Costs of Financial Distress across Industries.

[8] Emergency Management Australia (2002), Disaster Loss Assessment Guidelines, Part Iii, Emergency Management Practice, Volume 3-Guidelines, Guide 11.

[9] Hall John R., Jr. (2014), The Total Cost Of Fire In The United States, National Fire Protection Association (Napa), Fire Analysis And Research Division, U.S.A. 
[10] Abir Tareq Mahamud, (2014), Haphazard Industrialization And The Risk Of Fire: A Study On Garments Industries In Dhaka, Impact Journals, Vol. 2, Issn(E): 2321-8851; Issn(P): 2347-4580.

[11] Wadud, Huda and Ahmed, Assessment of Fire Risk in the Readymade Garment Industry in Dhaka, Bangladesh, http://link.springer.com/article/10.1007/s10694-013-0349-2

[12] National Human Rights Commission, Bangladesh (2014), Security And Safety Net Of Garments Workers: Need For Amendment Of Labour Law.

[13] Nath. B.H. (2000) 'Insurance and Risk Management'. Tanim Publication, 38 Bangla Bazar, Dhaka, Bangladesh.

[14] Omar, F.M. (2015) 'Compliance and Audit'.Grantha Nir Publication, 37/7, Azimpur Road, Dhaka, Bangladesh.

[15] Mudan, K.S. and Croce, P.A., (1988) Fire Hazard Calculations for Large Open Hydro-carbon Fires, The SFPE Handbook of Fire Protection Engineering, National Fire Protection Association, pp. 2.45-2.87.
[16] Thomas, P.H., (1963) The Size of Flames from Natural Fires, 9th Int. Combustion Symposium, Comb. Inst., Pittsburgh, PA, pp. 844-859.

[17] Eisenberg, N.A., Lynch, C.J. and Breeding, R.J., (1975), Vulnerability Model. A.

[18] Simulation System for Assessing Damage Resulting from Marine Spills. Nat. Tech. Inf. Service Rep. AD-A015-245 (Springfield. Va.).

[19] Lees, F.P.(1980), Loss Prevention in the Process Industries, Butterworth \& Co Ltd,.

[20] Chen, C.J. and Rodi, W. (1980), Vertical Turbulent Buoyant Jets - A Review of Experimental Data, HMT, The Science Applications of Heat and Mass Transfer, Volume 4, Pergamon Press.

[21] Harris, R.J.(1983), The Investigation and Control of Gas Explosions in Buildings and Heating Plant, British Gas.

[22] CPD's Rapid Assessment of Flood 2004, (2005), Options for Self - reliant Resurgence, ISBN 9840517090. 